\section{Tuberculous pericarditis}

EDITOR,-The case of tuberculous pericarditis presented by $\mathbf{C} P$ Clifford and $G$ J Davies contained a misleading characterisation of the findings on admission as classic tamponade. Kussmaul's sign and an abnormal third heart sound are inconsistent with the physiology of classic tamponade. ${ }^{2}$ Indeed, it is the virtual elimination of the rapid filling period necessary to produce a third heart sound that is a classic feature of tamponade. It is far more likely that this patient already had, under the tamponading fluid, an epicardial constriction with its typically mixed picture; a pulsus paradoxus with a $20 \mathrm{~mm} \mathrm{Hg}$ fall in blood pressure is unusual while a third heart sound and Kussmaul's sign are the rule in constriction. Although acute tuberculous pericarditis can progress rapidly to acute or subacute constriction, this was not such a case. ${ }^{34}$

Finally, I wish to argue against the term "pericardial knock." The abnormal early diastolic sound of constrictive pericarditis does not usually present an auscultatory knocking quality. More importantly, this description clouds concepts even if this form of the third heart sound did always "knock." The early diastolic sound of constrictive pericarditis is an especially early and often loud third heart sound with all necessary abnormal dynamics-accelerated early ventricular filling, with abrupt deceleration, into ventricles made abnormally stiff by pericardial scarring. ${ }^{4}$

Cardiology Division,

DAVID H SPODICK

St Vincent Hospital,

Worcester, MA01604,

USA

1 Clifford CP, Davies GJ. Tuberculous pericarditis with rapid progression to constriction. $B M 7$ 1993;307:1052-4.

2 Spodick DH. The normal and diseased pericardium: current concepts of pericardial physiology, diagnosis and treatment. I Am Coll Cardiol 1983;1:240-51.

3 Spodick DH. Tuberculous pericarditis. Arch Intern Med 1956;98: 737-49.

4 Spodick DH. Chronic and constrictive pericarditis. New York, Grune and Stratton, 1964:143-7, 204-9.

\section{Surgical castration for sex offenders}

\section{Mr K's wish granted}

EDrror,-Philip Joseph suggests that Mr K was merely bluffing in requesting that he should be castrated. ${ }^{1}$ Unless there are two such cases under debate, according to the Observer the man has had his operation at a private clinic in the south of England. ${ }^{2}$ If the report is reliable and refers to the same person, what will now be interesting is clinical follow up of his behaviour and subjective feelings.

London NW3 7LT

SHEILA R SILCOCK

1 Joseph P. Surgical castration for sex offenders. $B M \mathcal{F}$ 1993;307:1141. (30 October.)

2 Child abuser is castrated. Observer 1993 Oct 10

\section{Female castration controversy deserves same attention}

EDITOR,-The article on whether a sexual offender should be allowed castration is interesting because of its lack of attention to the issue in relation to women. ${ }^{1}$ Recent hospital activity data for North West Thames region suggest that $8-10 \%$ of women are castrated in Britain before the age of $55 .^{2}$ This is usually done as a prophylactic measure against ovarian cancer, although it is a controversial method of reducing the risk of ovarian cancer. Although ovarian cancer usually presents at an advanced stage, in the United Kingdom its incidence is 1 in 2500 women over the age of 55 and 1 in 3800 women over the age of $25 .^{3}$

Prophylactic oophorectomy is usually done as part of the routine process of hysterectomy. We have undertaken a study of the outcomes of hysterectomy in 363 women, during which we examined the issue of oophorectomy. Altogether 161 of the women had their ovaries removed. Review of the case notes showed that 26 of the removed ovaries were reported as showing signs of inflammation or endometriosis and that the rest were either normal $(n=80)$ or contained benign cysts $(n=55)$. Published reports show that the effects of routine prophylactic oophorectomy and its costs and benefits are unclear. ${ }^{4}$

We do not wish to comment on whether the (male) offender discussed in the article should be allowed castration. However, some of the arguments advanced in favour of more conservative treatment in this case might usefully be considered in the current controversy surrounding routine oophorectomy as prophylaxis against ovarian cancer.

\section{AILEEN CLARKE} PAM ROWE NICK BLACK

Department of Public Health and Policy,

Health Services Research Unit,

London School of Hygiene and Tropical Medicine,

London WC1E 7HT

1 Alexander M, Gunn J, Cook DAG, Taylor PJ, Finch J. Should a sexual offender be allowed surgical castration? $B M g$ 1993;307:790-3. (25 September.)

2 Howard G. North West Thames Regional Health Authority routine hospital episodes statistics. London: North West Thames hospital episodes statistics. Londor

3 Villard Macintosh L, Vessey M, Jones L. The effects of oral contraceptives and parity on ovarian cancer trends in women contraceptives and parity on ovarian cancer trends in wo

4 Speroff T, Dawson NV, Speroff L, Haber RJ. A risk benefit analysis of elective bilateral oophorectomy: effect of changes in compliance with estrogen therapy on outcome. Am $\mathcal{f}$ Obstet Gynecol 1991;164:165-74.

\section{Human rights in Israeli occupied territories}

EDITOR,-Successive reports by Amnesty International and other human rights bodies about the torture of Palestinian detainees during interrogation have become more difficult to ignore within Israel. Exposure of the institutionalised collusion of doctors during military service has recently forced the Israeli Medical Association to take a stand on this issue.

At an international conference, "Mental Health and the Challenge of Peace," held in Gaza in midSeptember-the first of its kind in the occupied territories-evidence was produced of the after effects of these experiences for victims. The Gaza Community Mental Health Programme, hosts to the conference, recently studied 477 men within six months of release from imprisonment during the intifada (F Abu Hein et al, unpublished data) The commonest form of torture, experienced by $85 \%$ of subjects, was of methodical assaults by team of men, each of whom had an assigned task. A particular focus was the genitals, and transien suffocation was also common. One interrogator often had the job of signalling to his colleagues when the prisoner was unconscious or had indicated that he was ready to talk. Ninety five per cent of convictions in military courts are based solely on a confession. Even after release, regular surveillance and night raids on their homes conveyed to these men that they were still not safe or free.

The study found that $26 \%$ of subjects had physical symptoms associated with their genitalia, $17 \%$ were depressed, and $40 \%$ had seven or more symptoms of post-traumatic stress disorder. Thei hypervigilance and suspiciousness impinged on others, with around $40 \%$ reporting family or marital problems and social withdrawal. Moreover, the communities in which they must recover have been traumatised by six years of violence that spared no one; more than $20 \%$ of the 1000 people killed by the Israeli army in Gaza and the West Bank were children, and all social, economic, and academic life has been subject to the imperatives of military occupation. Gaza's shattered infrastructure must support one of the most densely populated zones in the world; three quarters of its 800000 inhabitants are refugees.

The report's psychological findings are worrying, given that an estimated 80000 Palestinian men have been imprisoned since 1987 and 13000 are still held. However, it may be a good augury that the conference coincided with the signing of the peace accord in Washington, an event unforeseen here even two weeks earlier. Recognition of Palestinians' aspirations to shape their own future and the prospect of an end to an endemic conflict will give these men the chance to rebuild their society and thus themselves. Though some will need professional help, the definitive treatment for victims of torture is not psychotherapy but social justice.

Medical Foundation for the Care of

Victims of Torture,

London NW5 3EJ

1 Siegel-Itzkovich J. Israeli doctors banned from role in interrogation. BMF 1993;307:150-1. (17 July.)

\section{Dietary nicotine}

\section{Won't mislead on passive smoking ...}

EDrTor,-Domino et al have argued that the plasma cotinine concentration in non-smokers, which is taken as an index of passive smoking, may be confounded by dietary nicotine intake from vegetables of the family Solanaceae. ${ }^{1}$ They report that eggplant (aubergine) had the most nicotine of any Solanaceae. If their data are taken at face value, daily consumption of a $174 \mathrm{~g}$ serving of baked eggplant with gourmet tomato sauce made from purée yields a maximum dietary nicotine dose of $15 \mu \mathrm{g}$ (table), assuming (dubiously) that nicotine does not evaporate during baking. The mean daily total intake of all vegetables, however, is about $207 \mathrm{~g}$ for adults in the United States. ${ }^{2} \mathrm{~A}$ diet in which the daily average vegetable intake consists $84 \%$ by weight of eggplant parmigiana is unlikely for even the most fanatical gourmet, much less an average person, whose consumption of eggplant is

Nicotine dose and plasma cotinine concentration resulting from diet and passive smoking in typical and most exposed non-smokers

\begin{tabular}{|c|c|c|c|c|}
\hline & \multicolumn{2}{|c|}{$\begin{array}{c}\text { Estimated nicotine } \\
\text { dose }(\mu \mathrm{g} / \text { day })^{\star}\end{array}$} & \multicolumn{2}{|c|}{$\begin{array}{l}\text { Estimated plasma } \\
\text { cotinine }(\mathrm{nmol} / \mathrm{l}) \dagger\end{array}$} \\
\hline & Diet & $\begin{array}{c}\text { Environ- } \\
\text { mental } \\
\text { tobacco } \\
\text { smoke }^{6}\end{array}$ & Diets & $\begin{array}{c}\text { Environ- } \\
\text { mental } \\
\text { tobacco } \\
\text { smoke }^{6}\end{array}$ \\
\hline $\begin{array}{l}\text { Typical } \\
\text { Most exposed }\end{array}$ & $\begin{array}{r}0.7 \| \\
15.09\end{array}$ & $\begin{array}{r}100 \\
1000\end{array}$ & $\begin{array}{l}0.04 \\
0.86\end{array}$ & $\begin{array}{r}5 \cdot 7 \\
57 \cdot 0\end{array}$ \\
\hline
\end{tabular}

*All dietary nicotine [4] and $70 \%$ of nicotine from passive smoking nicotine [5] is absorbed.

†100 $\mu \mathrm{g}$ nicotine absorbed daily yields $5.7 \mathrm{nmol}$ cotinine/ plasma.[6]

¥Assuming that daily consumption of $10 \mathrm{~g}$ eggplant, $19.2 \mathrm{~g}$ tomato purée, $65.4 \mathrm{~g}$ tomatoes, and $239 \mathrm{~g}$ potatoes yields dietary nicotine intake of $1 \mu \mathrm{g}$. [1]

Cotinine: $1 \mathrm{ng} / \mathrm{ml}=5.7 \mathrm{nmol}$.

|Tomatoes and potatoes represent respectively $27 \mathrm{~g}$ and $75 \mathrm{~g}$ of The $207 \mathrm{~g}$ daily vegetable intake for adults, [3] or $49 \%$ of the
the the $207 \mathrm{~g}$ daily vegetable intake for adults, [3] or $49 \%$ of the
total. The corresponding American average dietary nicotine total. The corresponding American average di
dose is $((27 \times 1 / 65.4)+(75 \times 1 / 239))=0.7 \mu \mathrm{g} /$ day.

dose is $((27 \times 1 / 65.4)+(75 \times 1 / 239))=0.7 \mu \mathrm{g} /$ day.
IConsuming $116 \mathrm{~g}$ eggplant with $58 \mathrm{~g}$ tomato puré daily SConsuming $116 \mathrm{~g}$ eggplant with $58 \mathrm{~g}$ tomato purée daily
yields a maximum dietary nicotine dose of $((116 \times 1 / 10)+(58 \times$ yields a maximum die
$1 / 19 \cdot 2))=15 \mu \mathrm{g} /$ day. 